\title{
Mehmed Said Efendi’nin Misâha Risâlesi
}

\section{Mehmed Said Effendi's Treatise on Land-Surveying}

\author{
Atilla Polat ${ }^{1}\left(\right.$ ), Halime Mücella Demirhan Çavuşoğlu ${ }^{2}$ @
}

'Arş. Gör., İstanbul Üniversitesi, Edebiyat Fakültesi, Bilim Tarihi Bölümü, İstanbul, Türkiye

²Doktora öğrencisi, Ankara Üniversitesi Illahiyat Fakültesi, İslam Tarihi ve Sanatları Anabilim Dalı, İslam Tarihi Bölümü, İstanbul, Türkiye

ORCID: A.P. 0000-0002-4300-4381;

H.M.D.Ç. 0000000241261982

\section{Sorumlu yazar/Corresponding author:} Atilla Polat,

İstanbul Üniversitesi, Edebiyat Fakültesi, Bilim Tarihi Bölümü, İstanbul, Türkiye

E-posta/E-mail: atilla.polat@istanbul.edu.tr

Başvuru/Submitted: 25.11.2019 Revizyon Talebi/Revision Requested: 14.01.2020

Son Revizyon/Last Revision Received:

27.04.2020

Kabul/Accepted: 10.05 .2020

Online Yayın/Published Online: 03.07.2020

Atıf/Citation: Polat, Atilla ve Demirhan Çavuşoğlu, Halime Mücella. "Mehmed Said Efendi'nin Misâha Risâlesi." Osmanlı Bilimi Araştırmaları 21, 2 (2020): 249-270. https://doi.org/10.26650/oba.650926

\section{öz}

Mehmed Said Efendi (ö. 1767), Humbaracı Ahmed Paşa (1675-1747) olarak tanınan Claude Alexandre de Bonneval'in idaresi altında 1735 yılında kurulan Ulûfeli Humbaracı Ocağı́nda mühendis hocası olarak görev yapmıştır. Said Efendi'nin geometri ve astronomi alanlarında telif ve tercüme olarak birçok eseri bulunmaktadır. Kendisinin icat ettiğini söylediği rub'-ı müceyyeb-i zü'lkavseyn (veya diğer ismiyle müsellesiye) adlı mühendislik aleti üzerine olan risâlesi ile Avrupa kaynaklarından tercüme ederek hazırladığı pergâr-ı nisbe aletini anlattığı risâlesi Mehmed Said Efendi'nin bilimsel aletlere olan ilgisini göstermektedir. Daha önce incelenmiş olan yukarıdaki risâlelere ek olarak, bu çalışmada Mehmed Said Efendi'nin 1154/1741 senesinde el-Hacc (Şehlâ) Ahmed Paşa için hazırladığı ve arazi ölçümünde (misâha) kullanılan tabla aletinden bahsettiği risâlesi tanıtılacaktır. Eserin yeni bulunan nüshalarından bahsedilecek ve çeviriyazısı da verilecektir. Bu risâle, Ebu SehI Nu'mân Efendi'nin tabla aleti üzerine olan Tebyînü A'mâli'l-Misâha adlı eseriyle aynı dönemde yazıldığından iki eser arasında bir ilişki olup olmadığı üzerinde de durulacaktır.

Anahtar sözcükler: Mehmed Said Efendi, geometri, tabla, misâha

\section{ABSTRACT}

Mehmed Said Effendi (d. 1767) was an engineering teacher at the Ulûfeli Humbaracı Ocağı (The Corps of Salaried Bombardiers), founded in 1735 under the direction of Claude Alexandre de Bonneval (alias Humbaracı Ahmed Pasha, 1675-1747) in Istanbul. A treatise he composed on an engineering instrument rub'-ı müceyyeb-i zü'l-kavseyn (or müsellesiye - the trigonometrical instrument), which he says he invented, and another one on pergâr-ı nisbe (the sector) compiled from European sources, witness his interest in scientific instruments. This article will introduce Mehmed Said's treatise which describes the plane table used in land-surveying (misâha) dated 1154/1741. Recently found copies will also be mentioned and a Romanized text of the treatise will also be given. Mehmed Said's treatise was penned in a period when Ebu Sehl Nu'mân Effendi wrote his Tebyînü A'mâli'l-Misâha, also dealing with the plane table. The present study will also emphasize the possible relationship between the two works.

Keywords: Mehmed Said Effendi, geometry, plane table, land-surveying 


\section{Giriş}

Mehmed Said Efendi (ö. 1181/1767), on sekizinci yüzyılda İstanbul'da yaşamış matematikçi ve astronomlardandır. I. Mahmud döneminde (1730-1754) açılan Humbaracı Ocağında geometri hocalığı da yapan Mehmed Said Efendi hakkında bilgi veren üç kaynak vardır: Bunlardan ilki Bursalı Mehmet Tahir'in Osmanlı Müellifleri, ikincisi ise Osmanlı Matematik Literatürü Tarihi ve Osmanll Astronomi Literatürü Tarihi'nde bulunan Said Efendi maddeleridir. Mustafa Kaçar'ın doçentlik tezi olarak ve daha sonra Atilla Bir ile birlikte hazırladıkları çalışmalarda ise, hem Said Efendi'nin hayatı hakkında ilk iki kaynaktan daha kapsamlı bilgiler yer almış, hem de müellifin bazı risâleleri incelenerek bu risâlelerin bilimsel yönleri ortaya çıkarılmaya çalışılmıştır. ${ }^{1}$ Matematik ve astronomi aletleri üzerine eserler vermiş olan Mehmed Said Efendi, bu çalışmaya konu olan misâha risâlesini 1154/1741 senesinde el-Hacc Ahmed Paşa² için hazırlamıştır. Arazi ölçümünde (misâha) kullanılan tabla ${ }^{3}$ adı verilen bir aletten bahseden bu risâlenin, şimdiye kadar yaptı̆̆ımız araştırmalara

1 Ekmeleddin İhsanoğlu, Ramazan Şeşen ve Cevat İzgi, Osmanlı Matematik Literatürü Tarihi, C. 1. (İstanbul: İslâm Tarih, Sanat ve Kültür Araştırma Merkezi (IRCICA), 1999), 212-214; Ekmeleddin İhsanoğlu ve Ramazan Şeşen. Osmanlı Astronomi Literatürü Tarihi, C. 2. (İstanbul: İslâm Tarih, Sanat ve Kültür Araştırma Merkezi (IRCICA), 1997), 458-461; Bursalı Mehmed Tahir Efendi, Osmanlı Müellifleri, C. 3. haz. İsmail Özen (2. bs., İstanbul: Meral Yayınları, 1975), 292; Mustafa Kaçar, "İlk Osmanlı Mühendis Hocası Mehmed Said Efendi ve İcad Ettiği Rub'-1 Müceyyeb-i Zülkavseyn (Müsellesiye) Adlı Mühendislik Aleti," (Doçentlik tezi, İstanbul Üniversitesi, 2000); Mustafa Kaçar ve Atilla Bir, "Osmanlı Mühendislerinden Mehmed Said Efendi'nin Dikey Duvar Saatleri Hakkındaki Risalesi," Osmanlı Bilimi Araştırmaları 3, 1 (2001): 1-18; Mustafa Kaçar ve Atilla Bir, "Ottoman Engineer Mehmed Said Efendi and His Works on a Geodesical Instrument (Müsellesiye)," Multicultural Science in the Ottoman Empire, ed. Ekmeleddin Ihsanoglu, Kostas Chatzis ve Efthymios Nicolaïdis (Turnhout: Brepols Publishers, 2003) içinde, 71-89; Atilla Bir ve Mustafa Kaçar, "Ottoman Engineer Mehmed Said Efendi and His Treatise on Vertical Sundial," Multicultural Science in the Ottoman Empire, ed. Ekmeleddin İhsanoglu, Kostas Chatzis ve Efthymios Nicolaïdis (Turnhout: Brepols Publishers, 2003) içinde, 91-105. Bunların yanında Mehmed Said Efendi'nin Manzum Küre Tarifnamesi de neşredilmiştir, bk. Muhammed Said, Manzum Küre Tarifnamesi, çev. Tahir Nejat Gencan (İstanbul: Kandilli Rasathanesi, Kandilli Rasathanesi Bilim Tarihi Yayınlar1 9, 1973).

2 Burada bahsedilen Ahmed Paşa, 1740-1742 yılları arasında sadrazamlık yapmış olan Şehlâ Ahmed Paşa (ö. 1753) olmalıdır. Bk. Feridun Emecen, "Ahmed Paşa, Şehlâ,” Türkiye Diyanet Vakfi İslâm Ansiklopedisi, C. 2 (İstanbul: Türkiye Diyanet Vakfi, 2007), 114.

3 İngilizce ismi Plain/Plane Table olan bu aletin ismi eski harfli Türkçe sözlüklerde plançete (يڤّ) veya mesâha tablası olarak da geçmektedir: Kāmûs-ı Riyâziyât'ta planchette (Salih Zeki, Kāmûs-ı Riyâziyât, C. 4., İstanbul Üniversitesi Nadir Eserler Kütüphanesi, T911, 235); Kāmûs-ı Türkî’ de Fransizca planchette'den misâha tahtas1 (Şemseddin Sami, Kāmûs-ı Türk̂̀, İstanbul: İkdam Matbaası, 1317, 357); Lehçe-i Osmânî'de İtalyanca'dan misâha tahtası (Ahmed Vefik Paşa, Lehçe-i Osmanî İstanbul: Mahmud Bey Matbaası, 1306, 273); Lügat-l Nâci'de Fransızca'dan misâha tahtası (Muallim Naci, Lugat-l Naci, İstanbul: Asr Matbaas1, 1317, 194); Kāmûs-ı Osmânî'de İtalyanca'dan küçük tahta, misâha tahtası (Mehmed Salâhî, Kāmûs-ı Osmânî, C. 2, İstanbul: Mahmud Bey Matbaası, 1313, 346), Fransızcası ise blanchette (يلانشت); Kāmûs-ı Fransevî̀ de küçük tahta, tahtacık, harita aleti (Samy Bey Fraschery, Kāmûs-ı Fransevî Fransızcadan Türkçeye Lügat Kitabı, 4.bs., İstanbul: Mihran Matbaas1, 1322, 1707); Redhouse'un A Turkish and English Lexicon'unda Fransızca planchette'den "a surveyor's plane-table" (J. W. Redhouse, A Turkish and English Lexicon, Constantinople: Boyajiyan, 1890, 451); Mehmed Bahaeddin Toven'in Yeni Türkçe Lügatinde misâha tahtası (Bahaeddin, Türkçe Lügat, İstanbul: İkbal Kitabhanesi, 1336, 305); Raif Necdet Kestelli’nin Resimli Türkçe Kāmûs'unda Fransızca'dan misâha tahtası (Raif Necdet [Kestelli] ve Hasan Bedreddin, Resimli Türkçe Kāmûs, 2. bs., İstanbul, 1927, 189); Ali Seydi'nin Resimli Kâmûs-ı Osmân̂̂’sinde "harita almaya mahsus ve bir sehpa üzerine 
göre, konu hakkında yazılmış en eski Türkçe müstakil eserlerden biri olma ihtimali vardır. Bu konuda yazılmış aynı tarihli bir diğer risâle ise Ebû Sehl Nu'mân Efendi'nin tabla aletini anlattı̆̆ 1 Tebyînü A 'mâli'l-Misâha adlı eseridir. ${ }^{4}$

\section{Risâletü'l-Misâha'nın nüshaları üzerine}

Osmanlı Matematik Literatürü'nde Risâlat al-Misâha $a^{5}$ ismiyle üç nüshası bilinen eserin, bu çalışma süresince üç yeni nüshası tespit edilmiştir. Altı nüshadan İstanbul Üniversitesi $n r$. T6847 ve Ali Emiri Riyaziye nr. 116 hariç, diğer dördü başka eserlerle birlikte ciltlenmiştir. Aşağıda nüshaların katalog bilgileri ile bu nüshaların bulundukları mecmualardaki diğer risalelerin isimleri verilmiştir: ${ }^{6}$

- Topkap1, Hazine, nr. 1753/4, vr. 37b-43a: Müellifi tarafindan 3 Şevval 1154'te istinsah edilmiştir. Mecmuanın başında iki manzume vardır (vr. 3b-7a; vr. 9b-15b). Bunlardan ikincisi olan Manzûme der Küretân-i Müteharriketân, Hollanda'dan Osmanlı'ya hediye gelen bir gökküresinden bahseder. Üçüncü sırada uzaktaki nesnelerin ölçümü için Mehmed Said Efendi'nin geliştirdiği müsellesiye adlı aletten bahseden Risâle-i Müsellesiye yer alır (vr. 18b-35a). Beşinci sırada, hemen bu çalışmanın konusu olan tabla aletiyle ilgili risalenin son sayfasında olmak üzere, astronomiyle ilgili $\mathrm{Nazm}$ der Tesviyye-i Büyût vardır (vr. 43a). Altıncı olarak rub'- m mukantaranın kullanımından bahseden bir risale (vr. 44b-47a) ve ardından Lâmiyyetü fi'l- 'Arûz adlı bir manzume (vr. 47b-51b) ve Lügazü'l-Mensûb şerhi gelir (vr. 52a-56b). Dokuzuncu siradaki eserde zekâtla ilgili bir nazım, cetvel ve bazı bilgiler bulunur (vr. 57a-58a). Onuncu risale Mehmed Said Efendi’nin kızına Kur’an okumayı öğretmek için hazırladığı

mevzu tahta, ekseriya üzerinde bir su tesviyesi ile bir de mıstara bulunur"' (Ali Seydi, Resimli Kāmûs-ı Osmânî, C. 1, İstanbul: Cihân Matbaası, 1330, 241).

4 Ebu Sehl Numan Efendi hakkında bk. İhsanoğlu, Şeşen ve İzgi, Osmanlı Matematik Literatürü Tarihi, C. 1, 198204; Ebû Sehl Nu'mân Efendi, Tedbîrât-ı Pesendîde (Beğenilmiş Tedbirler), haz. Ali İbrahim Savaş (Ankara: Türk Tarih Kurumu, 1999); Cevat İzgi, "Nûman Efendi, Eğinli," Türkiye Diyanet Vakfi İslâm Ansiklopedisi, C. 33 (İstanbul: Türkiye Diyanet Vakfi, 2007), 235-236; Ebu Sehl Numan Efendi’nin Tebyînü A 'mâli'l-Misâha adlı eserinden bahseden bir çalışma için bk. Atilla Polat ve Ali Demirci, "Kâtip Çelebi'nin Hendese Bilen Kadısına Müşahhas Bir Örnek: Eğinli Nu'mân Efendi," Sahn-ı Semân'dan Dârülfünûn'a Osmanlı'da İlim ve Fikir Dünyası Alimler, Müesseseler ve Fikrî Eserler XVIII. Yüzyıl, haz. Ahmet Hamdi Furat ve diğerleri (İstanbul: Zeytinburnu Belediyesi Kültür Yayınları, 2018) içinde, 2:157-177.

5 Aslına bakılırsa müellif eserine bir isim vermemiştir. Ancak, Topkapı Sarayı Müzesi, Hazine nr. $1753 / 4$ ve Kütahya Vahidpaşa nr. 729 nüshalarının yer aldığı mecmuaların başlarında eser için sırasıyla Risâle-i Uhrâ der Misâha ve Hendeseden Tabla şeklinde kayıt düşülmüştür. Bir karışıklığa mahal vermemek için bu çalışma boyunca eser Osmanlı Matematik Literatürü Tarihi'ndeki gibi Risâletü'l-Misâha ismiyle anılacaktır. Bunun yanında Bursalı Mehmed Tahir Bey, Osmanlı Müellifleri’nde Mustafa Sıdkī’ye (ö. 1183/1769) ait misâha hakkında bir risâleden bahseder. Verdiği açıklamaya bakıldığında Mustafa Sıdkī’ye nisbet ettiği eserin Mehmed Said Efendi’ninki olduğu anlaşılır. Bk. Bursalı Mehmed Tahir, Osmanlı Müellifleri, 287.

6 Mehmed Said Efendi, Risâletü'l-Misâha, İstanbul Üniversitesi Nadir Eserler Kütüphanesi, T6847, 9 yaprak; Kütahya, Vahidpaşa 729, 107b-114b; Millet Yazma Eser Kütüphanesi, Ali Emiri Riyaziye 116, 8 yaprak; Topkapı Sarayı Müzesi, Hazine 1753/4, 37b-43a; Topkapı Sarayı Müzesi, Hazine 609/1, 1b-8b; Topkap1 Saray1 Müzesi, Hazine 611/2, 41b-46a. 
Hediyyetü 't-Tâlibîn fî Ta 'lîmi'l-Kur'âni'l-Mubîn'dir (vr. 58b-67b). On birinci surada pergâr-l nisbe adlı geometri aletinden bahseden tamamlanmamış bir risale mevcuttur (vr. 68a-71b). Mecmuada bulunan son risalede ise $r u b$ '- - mukantara üzerine çizilecek bazı yörüngelerden bahsedilir (vr. 72b-74a). ${ }^{7}$

- $\quad$ Topkap1, Hazine, nr. 609/1, vr. 1b-8b: Mecmuada ikinci sirada yine Mehmed Said Efendi'nin telifi olan, mesafe ölçümü için kullanılan sinüs adı verilen bir alet tanıtılır (8b-10a). Ardından yine mesafe ölçümünde kullanılan mikyâs hakkında bir risale gelir (vr. 11a-12a). Mecmuada son olarak İsmail el-Hacc Mustafa-zâde'nin Sadrazam Yusuf Paşa için hazırladığı ve top atışlarında mesafe ölçümünden bahseden eser yer alır (13b-26b). ${ }^{8}$

- $\quad$ Ali Emiri, Riyaziye, nr. 116, 8 yaprak. Müstakil bir risaledir.

- İ́stanbul Üniversitesi Nadir Eserler Kütüphanesi, Türkçe Yazmalar, nr. 6847, 9 yaprak. Müstakil bir risaledir. Bu nüsha Osmanlı Matematik Literatürü Tarihi'nde Mehmed Said Efendi maddesinde görülmez. ${ }^{9}$

- Topkap1, Hazine, nr. 611/2, vr. 41b-46a: Hicri 1185'te istinsah edilmiştir. Bu nüsha Osmanlı Matematik Literatürü Tarihi'nde Mehmed Said Efendi maddesinde görülmez. Bu mecmuadaki ilk risale Eğinli Numan Efendi'nin Tebyînü A 'mâli'lMisâha adlı eseridir (vr. 1b-40b). Üçüncü sırada ise Mehmed Said Efendi'nin sinüs aleti hakkındaki risalesi gelmektedir (vr. 47b-48b).

7 Mehmed Said Efendi'nin eserlerinin ilk 10'u için mecmuanın başında (vr. 2b) bulunan listeden faydalanılmıştır. Said Efendi’nin geometri ve astronomi eserlerinin katalog bilgileri için bk. İhsanoğlu, Şeşen ve İzgi, Osmanlı Matematik Literatürü Tarihi, C. 1, 212-214; İhsanoğlu ve Şeşen, Osmanlı Astronomi Literatürü Tarihi, C. 2, 458-461.

8 İsmail el-Hacc Mustafa-zâde, Çınârî nisbesiyle şöhret bulan Çınârî İsmail Efendi'dir. Bk. İhsanoğlu, Şeşen ve İzgi, Osmanlı Matematik Literatürü Tarihi, C. 1, 250-251; Meltem Akbaş [Kocaman], "Halifezade, Çınarî İsmail Efendi b. Mustafa," Lexikon der bedeutenden Naturwissenschaftler, ed. Dieter Hoffmann, Huber Laitko, Staffan Müller-Wille, Bd. 2 (München: Elsevier, Spektrum Akademischer Verlag, 2004), 150-151.

9 Bu nüshadan Adnan Adıvar da şu şekilde bahsetmiştir: “Ancak, Üniversite kütüphanesinde (Yıldız, tıp, 178) yazarı bilinmeyen bir küçük risale vardır ki, bunda Atış cetveli denilen alet ve bununla uzaklıkların tayini tarif olunmaktadır. Eserin ciltlenirken bir kısmı kesilmiş olan kenarında -ki, bu hal yazmaların bazllarında ne yazık ki görülüyor-, bu aletin 1152 yılında Mevkufatî Mehmet Efendi başkanlığındaki sınır çizilmesi heyeti tarafindan kullanıldiğl yazılıdır. Acaba bu küçük risale, Sait Efendinin risalesinden özetlenmiş bir eser midir?" Bk. A. Adnan Adıvar, Osmanlı Türklerinde İlim (İstanbul: Remzi Kitabevi, 3.bs 1970), 165. Adıvar bu anonim risalenin Mehmed Sait Efendi’nin müsellesiye aletiyle ilgili risalesinden özetlendiğini düşünmüştür. Risalenin kenarındaki üç satırlık ve satır sonları kesilmiş olan not ise şöyledir: 1- bin yüz elli iki târihinde mevkūfâtî muhaddid Mehmed Efendi ma 'iyyetinde tahrîr-i hudûda ta' '... 2- olunduğumuz evândan sonra tabla ta 'bîr etdikleri âlet-i misâhanın birkaç dür... 3-resmine im 'ân-l nazar ve tenâvülü sehl olan murabba 'ina bir risâte(?) tahrîr olunm... Bu nüshanın diğer beş nüshadan farkı hamdele ve salveleden sonra gelen risalenin yazılış tarihi olan 1154 senesinin ve ithaf edildiği Sadrazam Ahmed Paşa'yla ilgili kısmın eksik oluşudur. Risâlenin sonunda verilen kütüphane kayıt sayfasında ise "Adnan" [Adnan Adıvar] imzalı birkaç satırlık bir bilgi notu vardır. 
- Kütahya, Vahidpaşa, nr. 729: vr. 107b-114b: Hicri 1188'te istinsah edilmiştir. Bu nüsha Osmanlı Matematik Literatürü Tarihi'nde Mehmed Said Efendi maddesinde görülmez. Mecmuadaki ilk eser 726 numarada kayıtlı Takiyüddin'e ait olan Reyhânatü'r-Rûh fî Resmi's-sa 'ât 'alâ Müsteviyi's-Sutûh'un tercümesidir. Ardından 727 numarada Takiyüddin'in Âlât-ı Rasadiyye'si gelir (vr. 76a-86a). Üçüncü sırada 728 numaralı Hendeseden Pergâr-ı Nisbet vardır (vr. 87a-106b). Bu risalenin son kısmında denizcilikte kullanılan pusulayı anlatan iki sayfalık küçük bir risale bulunur (vr. 105b-106a), ancak bu eser kütüphane kaydına girmemiştir. 730 numaralı risale denizcilikle ilgilidir; harita ve papamundi (mappa mundi)'den bahseder (vr. 115a-122a). 730/1'de kayıtlı eser yine denizcilikle ilgili Kitâbü'l-Mürûr ve'l- 'Ubûr fi'l-Berri ve'l-Buhûr'dur. 731/1 numarada Tuhfetü't-Tullâb fî Keyfiyyeti İstihrâci 'Amâl bi'l-Hisâb, 731/2'de Nüzhetü'n-Nâzır, 731/3'te ise Şifâü'l-Eskām fî Vaz'i Sa 'âti 'ale' $r$-Ruhâm adlı risaleler bulunur. ${ }^{10}$

Görüldüğü misâha risalesinin Ali Emiri ve İstanbul Üniversitesi dışındaki nüshaları geometri, bilimsel aletler, mesafe ölçümü konuları üzerine eserlerle birlikte ciltlenmiştir. $\mathrm{Bu}$ mecmualarda her ne kadar çoğunlukla bilimsel eserlere yer verilmiş olsa da, bunların seçimlerinde bir rastgelelik göze çarpmaktadır.

\section{Risâletü'l-Misâha'nın İçeriği}

Risâle iki nev 've bir hâtime olmak üzere toplam üç kısımdan oluşur. Başlıklar ve kısa içerikleri aşağıdaki gibidir.

- Nev`-i evvel (tarîk-i ‘amel, uygulamanın nasıl yapılacağı)

- $\quad$ Mukaddime (kullanılacak aletler: sepâ, tabla, mıstara, mikyâs)

- Bâb-1 evvel (bulunulan yer ile karşıdaki bir nokta arasındaki mesafenin ölçülmesi)

- Bâb-1 sâni (bulunulan yerin karşısında olan iki farklı nokta arasındaki mesafenin ölçülmesi)

- Nev'-i sânî ('amelin burhânı)

- Mukaddime (ispat için gerekli geometrik kavramlar, çıkarımlar ve önermeler)

- Maksad (bâb-1 evveldeki durumun ispatı)

- $\quad$ Mühimme (uzunluk ölçüleri)

$10 \mathrm{Bu}$ mecmuayla ilgili bilgilerin bir kısmı www.yazmalar.gov.tr sitesinden alınmıştır. Ancak gördüğ̈̈müz kadarıyla mecmuada bulunan risaleler kaydedilirken birçok hata yapılmış, bazı risalelerin görselleri başka eserlerinkiyle karıştırılmış, katalog numaraları da kısmen yanlış verilmiştir. 
- Hâtime (dört bekreli [çıkrık, makara] bir ölçüm aletinin tarifi)

Şimdi kısaca bu başlıklarda bahsedilenlere değinebiliriz. Nev'-i evvel, bir mukaddime ve iki bâbdan oluşmaktadır. Mukaddimede aletin parçalarından bahsedilmektedir. Sepâ: Her biri iki zirâ‘ uzunluğunda üç ayaktan oluşan ve tablanın üzerine konulduğu kısımdır. Ayakları pergâr gibi açılabilir. Ortasından bir hayt (ip) ve şâkūl (çekül) geçer. Tabla: Uzunluğu ve genişliği yarımşar zirâ‘ olan ve sepânın üzerine yerleştirilen kare şeklinde levhadır. Tablanın iki yanında uzunlamasına bulunan yarıklara kâğıt yerleştirilmekte ve birer çark yardımıyla bu kâğıt sarılmakta ve tabla, üzerine çizim yapılabilir hale gelmektedir. Mıstara: pirinçten imal edilen mıstaranın, usturlap idâdesi gibi, iki tarafında hedefe bulunur. Hedefelerden gözlemin kolay yapılabilmesi için sukbelerin (deliklerin) birinde bir yarık diğerinde ise ip geçecek kadar delik vardır. Mikyâs: Mıstara üzerine çizilmiş bir cetveldir. Her biri altı dakikaya bölünmüş yirmi dereceden oluşur. Bir derece, bir zirâ'; bir dakika ise dört isba' (parmak) karşılı̆̆ıdır. Mikyâs istenildiği takdirde tabla üzerine de çizilebilir veya derecesi yirmiden fazla veya az olarak da hazırlanabilir.

Bâb-ı evvel, gözlemcinin bulunduğu yer ile karşıda gözlenen bir nokta arasındaki mesafenin nasıl bulunacağı üzerinedir. İlk olarak gözlem yapılacak noktaya sepâ yerleştirilir ve tabla, sepânın üzerine düz bir biçimde konulur. Şâkūl serbest bırakılır ve indiği noktaya menşe denilir. Gözlenen nokta ise mer'î olarak adlandırılır. Sepâ ve tabla, yeni bir gözlem yapmak üzere menşeden başka bir noktaya taşınır ve vasat olarak adlandırılan bu noktaya bir alamet konur. Menşe ve vasat arası mesafe zirâ' ile ölçülür ve $d \imath l^{\prime}$-ı ma 'lûm denilen bu değer akılda tutulur. $\mathrm{Bu}$ vasat noktasından yine mistara üzerindeki hedefeler vasitasıyla mer' $\imath$ gözlenir ve tabladaki kâğıt üzerine mer '̂ye doğru bir hatt çizilir. Ardından, bulunulan noktadan menşe gözlenir ve yine mistara kullanılarak menşe ve vasat arasını gösteren bir hatt çizilir.

Bâb-ı sânî, gözlemcinin karşısında bulunan iki nokta arasındaki mesafenin bulunması üzerinedir.

$N e v '-i$ sânî, birinci ve ikinci bâblarda verilen uygulamaların ispatı üzerinedir. Bir mukaddime ve bir maksad üzerine düzenlenmiştir. Mukaddimede ispat için gerekli geometri terminolojisi verilir. Nokta: Asla bölünemez bir işarettir. Hatt (Çizgi): Sadece tûl (uzunluk) yönünden bölünebilir. Noktada sonlanır. Müstakīm (Doğru): Hattın doğrusuna denir. Münhanî (Eğri): Hattın eğrisine denir. Mütevâziyân (Paralel): İki müstakīm iki taraflarından sonsuza kadar uzatıldıklarında aralarındaki mesafe daima aynı kalırsa bunlara mütevâziyân (paralel) denir. Mütesâmitân (Paralel olmayan): Mütevâziyân olmayan müstakīmlere denir. Sath (Yüzey): Tûl (uzunluk) ve 'arz (en) yönünden bölünebilir. Hatt (çizgi) veya noktada sonlanır. Müstevî (Düzlem): Sathın düzüne denir. Muhaddeb: Sathın yumru olanına denir. Muka 'ar: Sathın çukur olanına denir. Zâviye-i musattaha (Düzlem açısı): İki hattın bir noktada birleşmesiyle oluşan köşeye denir. Hattlar bu zâviyenin (açının) dıl'larıdır (kenarları). Müstakīmüd'-dıl 'eyn (Düzkenar): İki hatt da müstakīm olduğunda oluşan açıdır. 'Amûd (Dik 
açı): Bir müstakīm, bir benzeri üzerine kā'im (dik) olduğunda aralarında oluşan açılardır. Münferece (Geniş açı): Kā’imden büyük olan açıya denir. Hâdde (Dar açı): Kā'imden küçük olan açıya denir. Şekl: Mahdûd (sınırlı) olandır. Müselles (Üçgen): Üç müstakīm ile sınırlı olan şekildir. Her bir müstakīm, müsellesin dıl'1dır (kenar). Kā'ide: Üçgenin kenarlarından biri. Sâkeyn: Üçgenin kā‘ide haricinde kalan diğer iki kenarı. Kā'imü’z-zâviye (Dik üçgen): Bir açısı kā'ime (dik) olan üçgen. Münferecüz'-zâviye (Geniş açılı üçgen): Bir açısı münferece (geniş) olan üçgen. Hâddü’z-zevâya (Dar açılı üçgen): Üç açısı da hâdde (dar) olan üçgen. Veter (Kenar): Her bir açının karşısında olan dıl' (kenar).

Ardından sadr altbaşlı̆ğ ile bazı geometrik çıkarımlar verilmektedir: Nokta, doğru, yüzey ve açının her biri kendi cinsiyle işlem görür; iki doğru bir noktada karşılaşıp (muttasıl) aralarında bir açı oluşursa artık bu ikisi bir doğru olmuş olur; bir çokluğa eşit olan iki farklı çokluk birbirine eşittir (Aynı şeye eşit olan şeyler birbirine de eşittir, Öklit 1. ortak kavram); tüm dik açılar bir aradadır (Tüm dik açılar birbirine eşittir, Öklit 4. belit); dik açılarla birlikte olan açılar da diktir; birbirine muntabık (çakışık) olan iki doğru, tek bir doğru hükmündedir; bir açının kenarları başka bir açının kenarlarıyla muntabık (çakışık) olsalar, bu iki açı aynıdır ve çakışıktır; bir üçgenin iki açısı başka bir üçgenin iki açısına eşit olsa, bu iki üçgenin üçüncü açıları dahi birbirine eşit olur.

Bu çıkarımların ardından dört örnek gelir. Bu örnekler Öklit'in Elemanlar'ının birinci kitabının on beş ve yirmi dokuzuncu önermeleri ile altıncı kitabın dördüncü önermesidir. ${ }^{11}$

Maksad'da ise gözlem sonucu tabla üzerindeki kâğıda aktarılan üçgenlerin yukarıda verilen temel geometri bilgileri yardımıyla ölçüm için nasıl kullanılacağı açıklanır.

Maksad'ın hemen devamında mühimme adlı bir bölüm daha vardır. Burada vurgulanmak istenen kâğıt üzerine aktarılan üçgenlerin köşe ve kenarları üzerinde gözlem yapılan civardaki nesnelerin (karye, kasaba, şehir, tepe, ağaç, vb.) mümkün olduğunca gösterilmesidir. Çünkü bu şekilde bölgenin misâha olunmuş bir haritası elde edilmiş olacaktır. Mühimme'de mütekaddimîn, müteahhirîn ve mimarlar usulünce uzunluk ölçüleri ve bu ölçülerin birbirlerine çevrimleriyle ilgili aşağıdaki bilgiler verilmektedir. ${ }^{12}$ Dikkati çeken bir husus

11 Sinan Sertöz'ün çevirisi ile: 1. Kitap, 15. Önerme: Kesişen iki doğrunun oluşturduğu ters köşe açıları eşittir... Doğal sonuç: Buradan açıkça görülür ki, eğer iki doğru birbirini keserse, kesişme noktasındaki açıları dört dik açıya eşit kılarlar. 1. Kitap, 29. Önerme: Eğer iki doğru paralelse bunları kesen bir doğrunun oluşturduğu ters iç açılar eşittir, dış açı karşı iç açıya eşittir ve aynı taraftaki iç açılar iki dik açıya eşittir. 6. Kitap, 4. Önerme: Eş açılı üçgenlerde eşit açıların etrafındaki kenarlar orantılıdır ve bunlar eşit açıları gören kenarlardır. Öklid, Öklid'in Elemanlarl, haz. Ali Sinan Sertöz (Ankara: TÜBİTAK, 2019), 17-18, 31-32, 180-181.

12 Burada mütekaddimîn ve müteahhirîn dönemiyle kastedilen için Ebu Sehl Numan Efendi'nin Tebyînü A 'mâli'lMisâha'sında bir ipucu vardır: "Ma'lûm ola ki ölçü bir mikdâr-1 mu'ayyen olmak lâzım ve lâbüdd olmağın Şârih-i Çagmînî tahkīk ve tavzîh ve Merhûm Kâtib Çelebi’nin cografya fennine müte‘allik olan müellefâtında tasrîh itdiği üzre bir zirâ'-1 cografyanın mütekaddimîni i'tibârlarında otuz iki isba' ve müteahhirîni ihtiyârlarında yirmi dört isba' olup isba' bi'l-ittifâk altı 'aded mu'tedil şa'îre...” Bu bilgiden hareketle Kâtip Çelebi ve sonrasıyla müteahhirîn döneminin kastedildiğini düşünmek mümkün gözüküyor. Bkz. Ebû Sehl Numan Efendi, Tebyînü A 'mâli'l-Misâha, Kandilli Rasathanesi, Türkçe Yazmalar 86, v. 18a. 
saatin bir uzunluk ölçüsü birimi olarak kullanılmasıdır. ${ }^{13}$ Aşağıda metinden tespit ettiğimiz ölçü birimleri ve bunların birbirlerine çevrimi listelenmiştir:

A'zâm-1 dâ'ire-i arz $=360$ derece; 1 derece $=20$ sâ'at

Hükemâya göre: 6 adet ortalama arpa $=1$ parmak

Mütekaddimîne göre: 32 parmak $=1$ zirâ‘; 3000 zirâ‘ $^{\text {‘ }}=1$ mîl; 3 mîl = 1 fersah

Müteahhirîne göre: 24 parmak $=1$ zirâ'; 4000 zirâa $^{6}=1$ mîl; 3 mîl= 1 fersah

(1 fersah mütekaddimîn ve müteahhirîn için aynı uzunluğa sahip)

Mütekaddimîne göre: 1 derece $=22+1 / 9$ fersah $=66+1 / 3$ mîl $=1$ yük 99000 zirâ‘ (kendi zirâ'larıyla) = 2 yük 65333 zirâ' ve 8 parmak (müteahhrirîn zirâ'iyla); 1 sâ'atin hissesi = 9950 zirâ‘ (kendi zirâ‘larıyla) = 13266 zirâ‘ ve 16 parmak (müteahhirîn zirâ'1yla) (1 yük = 100.000 zirâ'$\left.^{6}\right)$

Müteahhirîne göre: 1 derece $=19-1 / 9$ fersah $=56+2 / 3$ mîl $=2$ yük 26666 zirâ‘ ve 16 parmak (kendi zirâ'larıyla) = 1 yük 80000 zirâ‘ (mütekaddimînin zirâ‘'yla); 1 sâ‘atin hissesi

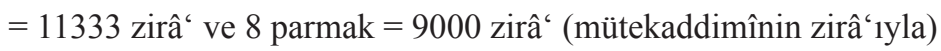

(Mi'mârların 24 parmak olarak kullandıkları zirâ', burada anlatılanlara göre 36 parmak olur. Mi'mârî parmak $=9$ tane mutedil arpa. Bu şekilde 2 mi‘mârî parmak, 3 parmaktan kinâyedir.)

Zirâ'-1 mi'mârî kullanılarak mütekaddimîne göre: 1 derece $=1$ yük 76888 zirâ' ve 21,5 parmak; 1 sâ'atin hissesi 8844 zirâ' ve 10,5 parmak

Zirâ'-1 mi'mârî kullanılarak müteahhirîne: 1 derece $=1$ yük 51111 zirâ' ve 2 parmak; 1 sâ'atin hissesi 7555 zirâ' ve 13 parmak.

(Burada verilen bilgilere göre ölçümü yapılan yerlerin saatleri bilinmiş olur.)

Hâtime bölümü, dağ ve kale gibi büyük cisimlerin şekillerinin kâğıt üzerine aktarılmasına yardımcı olan bir alet üzerinedir. Aletin ismi verilmemiştir. ${ }^{14}$

13 Eski harfli sözlüklerde de saat kelimesinin bir uzunluk ölçüsü olarak kullanıldığı görülmektedir: J. W. Redhouse'un A Turkish and English Lexicon 'unda "the distance usually walked by a traveler in one hour, being about three miles" (Redhouse, A Turkish and English Lexicon, 1028); Kāmûs-ı Türkî̀ de "bir saatte kat olunan yol miktarı ki üç mil yani beş kilometredir” (Şemseddin Sami, Kāmûs-ı Türkî, 699). Ayrıca bk. Cemal Çetin, “Osmanlılarda Mesafe Ölçümü ve Tarihî Süreci”, Prof. Dr. Nejat Göyünç Armağanı, ed. Hasan Bahar, Mustafa Toker, M. Ali Hacıgökmen ve Gül Küçükbezci (Konya: Selçuk Üniversitesi Türkiyat Araştırmaları Enstitüsü, 2013) içinde, 451-454.

$14 \mathrm{Bu}$ aletin Avrupa'daki hangi alete karşılık geldiği tarafımızca henüz belirlenememiştir. Bir teodolit veya grafometrenin yaptığı işi yapabilen bu alet şimdiye kadar görmüş olduğumuz teodolit ve grafometre 


\section{Mehmed Said ve Numan Efendi’lerin misâha risâlelerine genel bir bakış}

Daha önce de belirttiğimiz gibi bu çalışmaya konu olan Mehmed Said Efendi'nin misâha risâlesi ile aynı tarihi (1154/1741-42) taşıyan bir başka risâle Numan Efendi'nin Tebyînü Â'mâli'l-Misâha adlı eseridir. ${ }^{15}$ Belgrad Antlaşması'nın (1739) ardından OsmanlıNemçe (Avusturya) sınırlarının yeniden belirlenmesi için görevlendirilen heyette sınır mollası olan Ebu Sehl Numan Efendi, bu vazifesi sırasında karşılaştı̆̆ı olayları Tedbîrât-ı Pesendîde adlı eserinde anlatmıştır. ${ }^{16} \mathrm{Bu}$ eserde, sınırlar belirlenirken karşılaşılan zorluklar, Avusturya heyetinin Osmanlı'yı aldatma çabaları ve Numan Efendi'nin geometri bilgisi sayesinde bulmaya çalıştı̆̆ çözümler konu edilir. Numan Efendi bunun yanında Avusturyalı mühendislerin kullandığı tabla aletinin teorik ve pratik yönleri için de Tebyînü A 'mâli'lMisâha adlı eserini hazırlamıştır. Eserin içinde geçen 1154 tarihi aynı zamanda Tebyînü Á 'mâli'l-Misâha'nın ebced değeridir. Mehmed Said Efendi'nin risâlesinin müellif nüshasının ise 3 Şevval 1154 (12 Aralık 1741) tarihli olduğunu daha önce belirtmiştik. İki eserden hangisinin daha önce yazıldığ 1 ve müelliflerin birbirlerinin eserlerinden haberdar olup olmadığı konusunda şimdilik kesin bir şey söylemek mümkün değildir. Ancak, bu iki eser ve müellif arasında dolaylı da olsa bir irtibat olması ihtimal dâhilindedir.

Bu hususta dikkatimizi çeken ilk durum, makalenin önceki sayfalarında belirttiğimiz gibi Risâletü'l-Misâha'nın İstanbul Üniversitesi nüshasının baş tarafının kenarında üç satırlık ve satır sonları kesilmiş bir notta karşımıza çıkmıştı:

1. bin yüz elli iki târihinde mevkūfâtî muhaddid Mehmed Efendi ma‘iyyetinde tahrîr-i hudûda ta'...

2. olunduğumuz evândan sonra tabla ta 'bîr etdikleri âlet-i misâhanın birkaç dür...

3. resmine im‘ân-1 nazar ve tenâvülü sehl olan murabba'ına bir risâle(?) tahrîr olunm...”

Notu yazan kişi 1152 senesinde Mevkūfâtî Muhaddid Mehmed Efendi'nin maiyyetinde bulunduğunu söylemektedir. Buradan hareketle bu kişinin Numan Efendi olması mümkündür. $\mathrm{Bu}$ bilgi göz önünde bulundurulduğunda yine de hangi risâlenin daha önce tamamlandığ bilgisine kesin olarak ulaşamayız. Bunun yanında, bahsedilen heyete sonradan dâhil olan ve geometri bilgisiyle öne çıkan bir isim daha vardır: Abdullah Efendi el-Bosnavî. ${ }^{17}$ Numan

örnekleriyle tam olarak uyuşmadığı için şimdilik bir yorum yapmaktan kaçınıyoruz.

15 Ebû Sehl Numan Efendi. Tebyînü A'mâli’l-Misâha, Kandilli Rasathanesi, Türkçe Yazmalar 86, 99 yaprak; İstanbul Teknik Üniversitesi (İTÜ), Nadir Eser Koleksiyonu TA590.E.292 1741, 109 yaprak; Topkap1 Saray1 Müzesi, Hazine 611/1, 1a-40b.

16 Ebû Sehl Nu'mân, Tedbîrât-ı Pesendîde, 54-143.

17 Bosna'nın 1149-1152 (1736-1739) yıllarını anlatan bir eserde ismi "Muzafferzade Abdullah Çelebi” olarak geçmekte ve kendisinden "doğuştan yetenekli bir hüner sahibi” ş̧eklinde bahsedilmektedir. Bk. Ömer Bosnavî, Bosna Tarihi (Ankara: Kültür Bakanlığı, 1979), 116. 
Efendi, sınır ölçümünü detaylı biçimde anlattığı Tedbîrât-ı Pesendîde'de Bosnavî'den de kısaca bahsetmektedir. Osmanlı heyetinde ölçüm yapabilecek kabiliyette bir mühendis ve mimar bulunmadığından, Numan Efendi'nin teklifiyle Belgrad'dan bir mühendis talep edilir ve gelen Bosnavî olur. Bosnavî heyete dâhil olduğunda, Numan Efendi Avusturyalıların aletlerinin benzerlerini imal etmiş ve Bosnavî bunlarla ölçüm yapmıştır. ${ }^{18}$ Numan Efendi'nin anlatısında tabla ve diğer aletler hakkında Bosnavî'den bir bilgi edindiğine veya aralarında bu konularda bir konuşma gerçekleştiğine dair bir iz göremiyoruz. Bosnavî gibi bu konularda bilgi sahibi olduğunu düşündüğümüz birinin Numan Efendi'nin hikâyesinde daha fazla yer almasını beklemek doğal gözüküyor. Acaba tüm olayları detaylı biçimde anlatan Numan Efendi'nin Bosnavî'den bahsetmemesinin başka nedenleri olabilir mi, şimdilik bilmiyoruz.

İlginç olan bir diğer husus Bosnavî’nin Mehmed Said Efendi’yle de tanışıyor olmasıdır. Mehmed Said Efendi, Bosnavî ile 1147 senesinde Üsküdar'daki humbarahânede karşılaşmış ve Bosnavî’nin misâha ve mikāt ilmine dair iki eserinin günümüze ulaşmasını sağlamıştır. ${ }^{19}$

Hem Mehmed Said ve hem de Numan Efendi'nin risalelerinde inceledikleri aleti tabla olarak isimlendirmeleri ve de eserlerinin son kısımlarında ikisinin de dört bekreli bir aletten ${ }^{20}$ bahsetmesi, bizi aralarındaki ilişkiyi sorgulamaya yöneltir.

\section{Değerlendirme}

Mehmed Said Efendi'nin tabla aletini tanıttığı bu risâlesi konuyu müstakil biçimde ele alan Türkçe eserlerin ilklerinden olması bakımından önemlidir. Bu risâle, aynı konu üzerine ve muhtemelen aynı dönemde kaleme alınmış Ebu Sehl Numan Efendi'nin Tebyînü A 'mâli'lMisâha'sı kadar geniş ve detaylı değildir. Ancak bu durum Mehmed Said Efendi'nin üslubuyla ve eserin hedef kitlesiyle ilgili olmalıdır. Başka bir çalışmada kendisinin Pergâr-ı nisbe aleti üzerine bir tercümesi olduğundan ve Mehmed Said'in bu Türkçe tercümeye kaynak olarak kullandığı eserin başka mütercimlerce de çevrildiğinden bahsedilmişti. ${ }^{21}$ İncelemelere göre, çevirinin anlaşılabilirliği ve seçilen terimlerin uygunluğu bakımından Mehmed Said'in tercümesi diğerlerinden üstün gözükmektedir. Kendisinin medresede iyi bir öğrenim gördüğünü ve geometriastronomi konularında döneminin önemli bilginlerinden biri olduğunu söylemek mümkündür. Farklılığı ise - belki de Humbaracı Ocağındaki görevinin de etkisiyle - Avrupa kaynaklı "yeni” bilginin de farkında olması ve bu bilgiyi sahip olduğu klasik bilgiyle birleştirerek yeni eserler verme çabasında görülüyor. Astronomi üzerine kaleme aldığı eserlerin bir kısmı Arapça olsa da,

18 Ebû Sehl Nu'mân, Tedbirât-ı Pesendîde, 82-83.

19 İhsanoğlu, Şeşen ve İzgi, Osmanlı Matematik Literatürü, C. 1, 180; İhsanoğlu ve Şeşen, Osmanlı Astronomi Literatürü 1, 400-401. Bk. Kaçar ve Bir, Mehmed Said Efendi'nin Dikey Duvar Saatleri, 3.

20 Numan Efendi bu alete zâtü'l-bekre derken Mehmed Said Efendi bir isim vermemiştir. Zatü'l-bekre tabiri için bk. Ebû Sehl Nu'mân, Tebyîn, Kandilli Rasathanesi, Türkçe Yazmalar 86, 74a.

21 Polat, Atilla. "Treatises on Pergar-l Nisbe (the Sector) in Manuscript Collections in Turkey," Instruments Between East and West, ed. Neil Brown, Silke Ackermann ve Feza Günergun (Leiden \& Boston: Brill, 2019) içinde, 39-54. 
buradaki gibi geometri üzerine olan eserlerinde Türkçe'yi kullanıyor. Bu durum muhtemelen Humbaracı Ocağında hocalık yapmasından kaynaklanıyordu. Belki de eserlerinin nispeten kısa olması pratik amaca yönelik hazırlanmış olmalarıyla açıklanabilir. Ancak, her halükârda Türkçe ile bilim yaparak anlaşılabilme gayreti ve bundaki görece başarısı dikkat çekiyor.

Şimdi de bu çalışmaya konu olan risâlenin niçin ve kimler için hazırlanmış olabileceği sorusuna yanıt verebilecek bazı verileri değerlendirelim. Risâlenin dîbâcesinden sonraki ilk bölümünde önce tabla aleti ve parçaları tanıtılıyor ve akabinde iki uygulama ile aletin nasıl kullanılacağı anlatılıyor. İkinci bölümde ise geometri terimleri ve ilk bölümdeki uygulamanın ispatı/açıklaması veriliyor. Bu sıralamaya, yani uygulamanın teoriden önce gelmesine baktığımızda Mehmed Said Efendi’nin risâlesinin Humbaracı Ocağı öğrencileri veya muhaddid/mimar/mühendis adayları için bir el kitabı olarak hazırlanmış olabileceğini düşünebiliriz. İçerik olarak çok kapsamlı ve her konuya çözüm bulmayı sağlayabilecek bir eser olmadığı söylenebilir. Zira, sahada uygulama yaparak konuyu ayrıntısıyla öğrenen öğrencilerin kapsamlı bir esere muhtemelen ihtiyaçları yoktu.

Risâlenin yaygın biçimde kullanılıp kullanılmadığı hakkında kesin söz söylemek şimdilik zor gözüküyor. Nüshaların tamamının oldukça temiz durumda olması, üzerlerinde ekstra matematiksel işlemler ve notlar bulunmaması ve risâleye sonraki dönemlerde yapılmış atıflara -şimdilik - rastlamamamız eserin yaygınlaşmadığı yönündeki kanaatimizi güçlendiriyor. ${ }^{22}$

Risâlede yer alan uzunluk ölçüleriyle ilgili kısım ve verilen tablo da üzerinde durulmaya değer. Mütekaddimîn ve müteahhirîn tarafindan kullanılan ölçülere değinilmesi, bunların derlenerek hem birbirlerine hem de mimarların kullandığı ölçülere nasıl çevrileceklerinin anlatılması henüz ölçülerde standartlaşmanın görülmediği bir dönem için eserin pratik değerini arttırıyor.

Risâlenin hâtimesinde bahsedilen bekreli aletin ne olduğu maalesef bu çalışma sürecinde tespit edilemedi. Her ne kadar verilen tariften teodolit benzeri bir alet olduğu izlenimini uyandırsa da şimdilik kesin bir şekilde bir benzerine rastlamadığımız için bu hususta bir söz söylemekten kaçındık. Aynı alete Numan Efendi'nin de eserinde kısaca değindiğini biliyorduk. Bu ve başka sebeplerle iki eser arasında bir ilişki olma ihtimalini de göz önünde bulundurmamıza rağmen bu konuda da şimdilik bir öneride bulunmak mümkün gözükmüyor.

Mehmed Said ve Numan Efendiler'in tabla ismini verdikleri bu aletten bahseden başka kitapları incelediğimizde bu ikisinin eseri kadar konuya geniş biçimde değinen erken döneme

22 Mehmed Said Efendi'nin bu risâlesine kendisine yakın dönem eserlerde henüz bir atıf görmemiş olsak da "müsellesiye" adını verdiği aletle ilgili şu not dikkat çekicidir: "Mühendisînden Sa‘îd Efendi merhûmun ihtirâ'ları olunan rub'-1 dâ'ire-i ceyb-i zü’l-kavseyn ile müsellesin adlâ'ını ölçmek için ilm-i misâha bâbında mahsûs bir risâleleri dahi vardır. Lâkin mübtedî olanlara göre tefhîmi 'asîr olmakdan nâşî fehm u icrâsı âsân olmak için işbu pergâr "ameli derc u tastîr olunmuşdur..." Mustafa b. İbrahim, Fenn-i Humbara, İstanbul Atatürk Kitaplığg Muallim Cevdet Yazmaları, nr. K439, 57b-58a. 
ait (1750'ler civarı) başka bir esere şimdilik rastlamadık. Konu hakkında kapsamlı ve daha yeni usullere göre hazırlanmış eserler ise 1800'ler sonrasında karşımıza çıkıyor. Bu durum belki de aletin tabla değil de plançete ismiyle sözlüklerde yer almış olmasını açıklayabilir.

Son olarak da yeniden Mehmed Said ve Numan Efendiler'in dışında Bosnavî'yi hatırlatmakta yarar görüyoruz. Kendisinin bu iki isimle irtibat kurmuş olması, burada kısaca değindiğimiz noktaların ileride bulunması muhtemel bilgiler 1şı̆̆ında aydınlatılmasını sağlayabilecektir.

\section{Ek: Said Efendi’nin Misâha Risâlesi'nin Latin harflerine çevirisi}

Risâletü'l-Misâha (Topkapı Sarayı Müzesi, Hazine 1753, vr. 37b-43a.)23

[37b] Bismillâhi’r-rahmâni’r-rahîm

Hamd u şükr ve senâ-yı bî-nihâye cenâb-1 ferd u bî-çûn u kibriyâya, salât u selâm ve du'â-yı bî-gāye Hazret-i Rasûl Muhammed Mustafâ'ya ve tarziye vü ta‘zîm girân-mâye-i âl u ashâb-1 ûlâü'n-nühâyadır.

Ve ba'd, mûşikâfân-1 fenn-i hikmetden ba'zı feylesof basît-i gabrâda mikdârı ma'rûf olmayan sâhaların nazar ile misâhası ehemm-i mehâmm-1 devletden olmagın berâhîn-i hendesiyyeden birkaç eşkâl intizâ‘'yla bir âlet-i sehlü'l-isti'mâl ihtirâ' eyleyip sahîfe-i rûzgârda bir tuhfe-i yâdigâr ibdâ‘ eylemiş idi. Bu sâl-i ferec-i iştimâlde (1154) ol tuhfe netîcetü'l-kemâlden biri, destûr-1 gayûr-1 a'zam, sadru's-sudûr-1 efham, nâzım-1 umûr-1 'âlem, müdebbir-i cumhûr-1 ümem, vezîr-i bî-nazîr-i ekrem, rûşen-zâmîr-i kerrûbî-şiyem, âsaf-rây-1 vâlâ-himem, Aristo-yı tedbîr-i 'âlâ-yı 'ilm, müşterî-yi müşîr-i encüm-i hadem, sa'âdet-semîr-i mübârek kadem, ferruh-dem-i ferhunde-makdem, dakīka-şinâs-1 bütûn u zuhûr-1 hikem, veliyy-i 'aliyy-i evliyâu’’n-ni'am, câmi'ü’s-seyf ve'l-kalem, râfi'u'z-zulm ve’z-zulem, dâfi'-i keydü'n-nasârâ ve'l-'acem, sâhibü'd-devlet ve'l-mürüvvet ve'l-kerem, mecma'u'l-fuzalâ, merci'u'l-üdebâ, melce'u'l-fukarâ, mencâu'l-gurabâ, kehfü'r-re‘âyâ, melâzü'l-berâyâ, ebu'l-fazl ve'l-ma'ârif ve'n-nühâ, devletli, sa'âdetli, 'inâyetli, velîni ‘metim el-Hacc Ahmed Pâşâ, yesserallâhu te'âlâ lehu mâ yahtâr mine'l-hayr ve mâ yeşâ, hazretlerinin pîşgâh-1 devlet-i destgâhlarına vusûl, ve dîvânhâne-i i'tibârlarında hayyiz-i kabûl buldukda, zebân-1 tercümân-1 kalemden keyfiyyet-i a'mâl u burhânı beyân olunmak bâbında bende-i dîrîne mahfûfü'l-ihsânlarına fermân-1 vâcibü'l-iz'ânları sudûr bulmagla imtisâlen lehu bu risâle-i şetîtü’l-makāle tehzîb u tahrîr ve iki nev'le bir hâtime üzerine tertîb u tasvîr olundu, [38a] ve billâhi’t-tevfîk.

23 Çeviriyazı hazırlanırken basit transkripsiyon yöntemi tercih edilmiştir. Bunun yanında kelimelerin okunuşunda çoğunlukla günümüz telaffuzu tercih edilmiştir. Okunamayan kelimeler "?? ile, varak numaraları [ ] içinde gösterilmiştir. Risâlede yer alan dört şekil ve iki cetvel (tablo) tarafımızca çizilmiştir. 
Nev'-i evvel: Tarîk-i 'amel beyânındadır. Bir mukaddime ve iki bâbı müştemildir.

Mukaddime: Esâmi-yi eczâ ve rüsûmdadır. Sepâ, iki zirâ‘ mikdârı üç ayaklı nesnedir ki pergâr gibi her biri feth u zamm olunur. Vasatlarında hayt ile bir şâkūl âvîze olunmuşdur. Tabla, sepânın üzerine vaz' olunacak dört köşeli tûlen ve 'arzen nısf zirâ' mikdârı bir levhdir ki iki tarafında birbirine mukābil dıl'larına muvâzî iki şakk-ı tûlâni vardır. Ve her birinin altında hârice mâ'il kendilere muvâzî birer çubuk vaz' olunmuşdur ki ikisi dahi hareket-i vaz'iyye ile müteharriklerdir. Ve birer uçlarında birer yaylı çarh geçirilmişdir. Ve 'arzı, şakkların tûlundan nâkısca bir mustatîl kâğıd ol tablanın üzerinde bir ucu bir şakkdan ve bir âhar ucu şakk-1 diğerden tabla âletine geçirilip ol çubuklara sarılmışdır. Lâkin birine çubuk sarılmışdır ki 'amel olundukça andan çözülüp âhara sarıla. Mıstara, usturlâb 'izâdesi gibi iki başı hedefeli pirinç levhdir. Lâkin hedefelerin bedel-i sukbu birinde şakk ve birinde hayt kadar ince tel vardır ki hîn-i nazarda ru'yet sehl ola. Levh-i mezkûrun bir tarafı gāyet müstakīm ve merkez-i sukbeteyne mârdır. Harf-i mistara ta'bîr olunur. Mikyâs, mistara üzerinde mersûm bir cedveldir ki yirmi derece-i mütesâviyeye taksîm, ve fakat bir derecesi altı dakīkaya kısmet olunmuşdur. Bir derece, bir zirâ‘dan; ve bir dakīka, dört isba'den kinâyedir. Mikyâs, tabla üzerine resm olunmak, derecesi ziyâde ve noksân olmak dahi câ'izdir.

Bâb-ı evvel: Bir mevzi'in karşısında ru’yet olunan mahall ile mâbeyni ne mikdârdır, min-gayrı-kıyâs misâha olunmak beyânındadır. Evvelâ, mesâfesi murâd olunan fezânın nihâyetine mer 'î tesmiye olunup mevzi'-i kademe sepâ nasb ve üzerine tabla düz vaz've şâkūl âvihte kılınır. Maskat-1 şâkūla menşe tesmiye olunup menşeden mümkün olan tarafa bir mikdâr mahall murâd olunan zirâ' ile misâha olunup gāyetine bir kāme mikdârı 'alâmet nasb ve mevzi'-i 'alâmete vasat tesmiye olunur. Kaç zirâ' ise hifz olunup dıl'-l ma 'lûm denilir. Ba'dehu tablanın üzerine mistara [38b] vaz' olunup hedefelerinden mer'îye nazar ve ru'yet olundukda ol vaz' üzerine harf-i mistaraya muntabık bir hatt resm olunur. Ba'dehu mistarayı nasb olunan 'alâmet semtine vaz' ve hedefelerinden 'alâmete nazar olunup ru'yet olundukda ol vaz' üzerine dahi harf-1 mistaraya muntabık bir hatt dahi resm olunur. Hatt-1 sânî, hatt-1 evveli $A$ (') noktasında kat' eder. Ba'dehu hıfz olunan zirâ' 'adedince derece-i mikyâs 'add edip ol kadar pergâr feth olunup bir ayağı $A$ (') noktasına vaz' ve diger ayağıyla hatt-1 sânînin üzerine 'alâmet cânibine $B(ب)$ noktası resm olunup $A B$ (اب) hattı hâsıl olur, bu hatta dahi dıl'-ı ma'lûm denilir. Ba'dehu sepâ ile 'alâmetin mevzi'leri ibdâl olunur. Ya'nî sepâ, vasata; 'alâmet, menşeye nakl olunur. Şol şartla ki her birinin maskatü'l-haceri âharın maskatü'l-hacerine muntabık ola ve vasatda $A B$ (اب) hattına harf-i mıstara muntabık kılındıkda hedefelerden menşede 'alâmet yine ru'yet oluna. Bu iki şarta mürâ‘ât u ihtimâm olunmak vâcibdir, zîrâ cüz'î mesâfede hatâ-yı fâhiş ihtimâli vardır. Ba'de’l-mürâ‘ât hattlar vaz' üzerine bulunmuş olur. Ba'dehu harf-i mıstara $B(ب)$ noktasına mülazım kılınıp yine hedefelerden mer'îye nazar olunup ru’yet olundukda ol vaz' üzerine harf-1 mistaraya muntabık bir hatt resm olunur ki $B(ب)$ noktasından mürûr edip hatt-1 evveli $C$ (ج) noktasında 


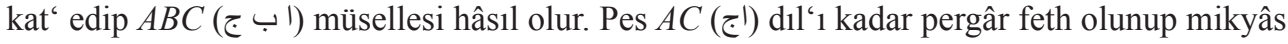
üzerine vaz' olunur, ne kat' ederse her derecesine bir zirâ' ve her dakīkasına dört isba' 'add olunup menşe ile mer'înin mâbeyni ol kadar olur. Ve kezâlik $B C$ (ب) d11'¹ bu uslûb üzere 'amel olunup vasat ile mer'înin mâbeyni ma'lûm olur.

Hîn-i ‘amelde mütevehhim olan şekildir:

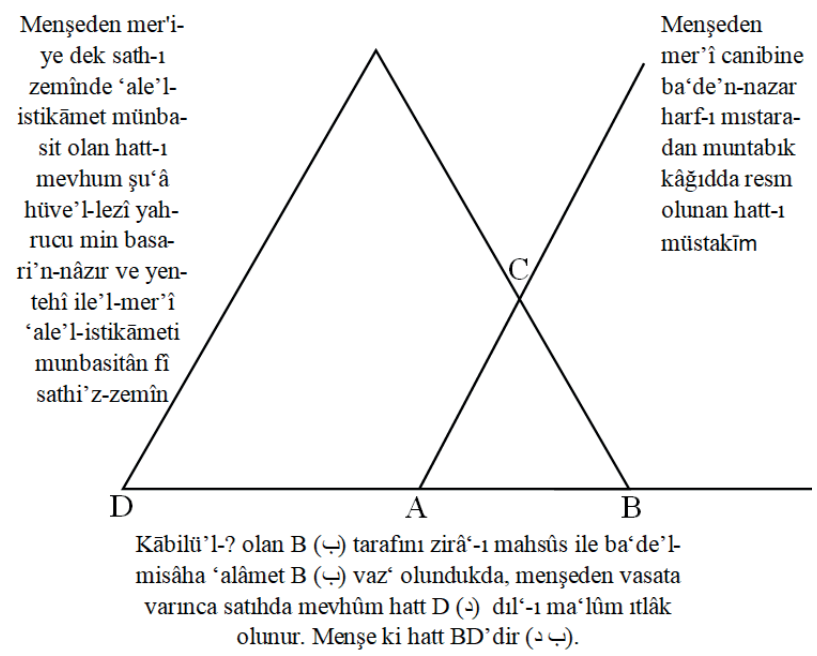

[39a]

Bâb-ı sânî: Karşıda mer'î olan iki nesnenin mâbeyni ne mikdârdır, kezâlik misâha olunmak beyânındadır. Ke'l-evvel sepâ, menşeye; 'alâmet vasata nasb olunup mâbeynleri misâha ve kaç zirâ‘ etdiği zabt olundukdan sonra kâğıd üzerinde evvelâ $A$ (') noktası vaz' olunup, ol noktaya harf-i mıstara mülâzım kılınıp, hedefelerden ibtidâ mer'înin biri ru'yet olunup $A C$ (جا) hattı resm olunup, sâniyen bir âharı dahi ru'yet olunup $A D$ (اد) hattı resm olunur. Sâlisen 'alâmet ru'yet olunup $A B$ (اب) hattı resm olunur ve $A B$ (اب) kemâ fi'l-evvel dıl'-1 ma'lûm kılınıp sepâ ve 'alâmet ibdâl olunur ve zikr olunan iki şarta mürâ‘ât olunur. Ba'dehu $B(ب)$ noktasına harf-i mistara mülâzım kılınıp evvelki mer'îye $B C$ (ب) hatt1, ikinci mer'îye $B D(ب)$ hattı resm olunup, d11'-1

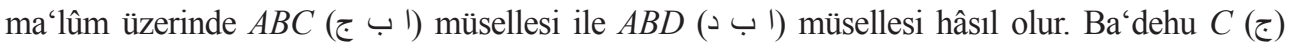
noktasıyla $D(د)$ noktası bir hatt-ı müstakīm ile vasl olunup pergâr ile mikyâsdan mikdârı tahsîl olunur. Ne kadar derece ise iki mer'înin mâbeyni ol kadar zirâ' ve ne kadar dakīka ise dört ol kadar isba“ etdiği ma 'lûm olur. Ve bu sûretde dahi menşe ile evvelki mer'înin mâbeyni $A C$ (اج) hattından ve ikinci mer'înin mâbeyni $A D$ (اد) hattından ve vasat ile evvelki mer'înin mâbeyni $B C$ (ج) hattından ve ikinci mer'înin mâbeyni $B D$ (ب) hattından ma'lûm olur, şekli budur: 


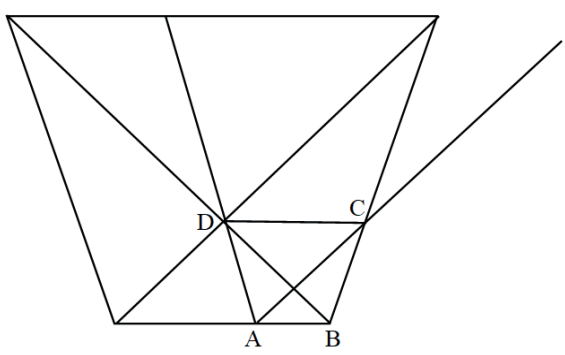

[39b]

Nev'-i sânî: Zikr olunan 'amelin burhânı beyânındadır. Bir mukaddime ve bir maksadı müştemildir.

Mukaddime: Burhânın mevkūfun-'aleyhâsı olan eşyâ beyânındadır. Hudûd: Nokta, aslâ kısmet kabûl etmez bir kābil-i işâretdir. Hatt, ancak bir cihetden kābil-i kısmetdir ki tûl derler, noktada müntehî olur. Doğrusuna müstakīm, eğrisine münhanî derler. İki müstakīm tarafeynden ilâ-gayri'n-nihâye ihrâc olundukda mâbeynleri dâ'ima berâber olursa mütevâziyân, olmazsa mütesâmitân derler. Sath, iki cihetden kābil-i kısmetdir ki birine tûl birine 'arz derler. Hattda, yâ noktada müntehî olur. Düzüne müstevî, yumrusuna muhaddeb, çukuruna muka 'ar derler. Zâviye-i musattaha, iki hatt bir noktada mültekī oldukda aralarında hâsıl olan köşedir. Hattlar, dıl'larıdır. İkisi dahi müstakīm olurlarsa zâviyeye müstakīmü'ddıl'eyn derler. Bir müstakīm, misli üzerine kā'im oldukda iki tarafında hudûs eden zaviyeler birbirine berâber olursa her birine $k \bar{a}$ 'im ve müstakīmlerin her birine aharın üzerine 'amûd derler. Kā'imden büyük olan zâviyeye münferece, küçük olana hâdde derler. Şekl, mahdûd olandır. Hadd, nihâyete derler. Müselles, üç müstakīm ile mahdûd olan şekldir. Her bir müstakīm, dıl'ıdır. Birine kā'ide denilse, bâkīlere sâkeyn derler. Üç zâviyesi [40a] vardır. Biri kā'ime olsa müsellese, kā'imü'z-zâviye; münferece olsa, münferecüz'-zâviye; üçü de hâdde olsa, hâddü'z-zevâya derler. Her zâviyesinin mukābilinde olan dil'a veter derler.

Sadr:

Nokta, hatt ve sath, zâviyeden her biri kendi cinsine tatbîk olunur.

İki müstakīm bir noktada muttasıl olup zâviye hâdis olmasa, müstakīm-i vâhid olur.

Bir mikdâra başka başka müsâvî olan olan iki mikdâr birbirine mütesâvîlerdir.

Cemî‘-i kā’imeler berâberlerdir, kā’imeye berâber olan zâviyeler dahi kā’imedir. 
Birbirine muntabık olan iki müstakīm, vâhid hükmündedir.

Bir zâviyenin dıl'ları, bir âhar zâviyenin dıl'larına bi’t-tenâzur muntabık olsalar, zâviyeler berâberlerdir ve muntabıklardır.

Bir müsellesin iki zâviyesi, âhar müsellesin iki zâviyesine berâber olsalar, üçüncü zâviyeleri dahi birbirine berâberdir.

\section{Mesâ'il:}

A ('): Bir müstakīm iki mütevâzîyi birer nokta üzerinde kat' eyledikde her bir tarafında dört zâviye hâdis olur. İkisi dâhile, ikisi hârice; mecmû‘u sekiz zâviye olur. Dördü bir noktanın etrâfında ve dördü diğer noktanın etrâfında, her bir noktanın etrâfında vâki ‘ olan dört zâviye ki, ikisi dâhile ve ikisi hâricedir, yâ dört kā'imedir, yâ dört kā’imeye berâberdir.
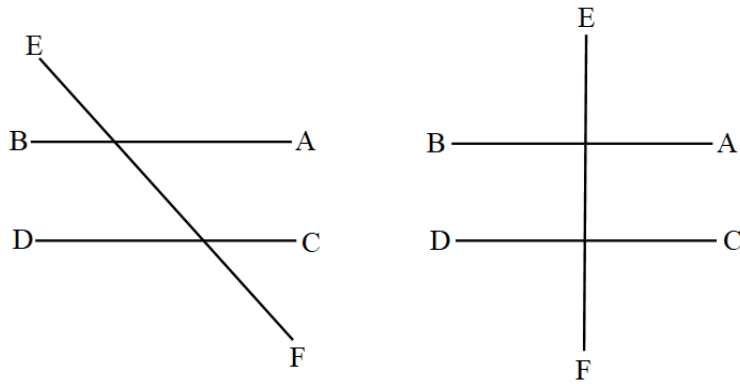

Ve zikr olunan sekiz zâviyeden birbirine mücâvir olan, ya'nî bir dıl'da müşterek iki zâviye, mutlaka yâ iki kā'imedir, yâ iki kā'imeye berâberdir. Ve ancak bir noktada mültekī olan hârice ve dâhile berâberlerdir, usûl-i Öklîdisden makāle-i ûlânın on beşinci şekliyle.

B (ب): Ve bir tarafda vâkı'a olup birbirine mücâvir olmayan dâhile ve hârice berâberlerdir. Ve bir tarafda vâk1'a olan bir noktanın hâricesi âhar tarafda vâk1'a olan diger noktanın hâricesine ve kezâlik dâhilesi dâhilesine berâberdir, makāle-i mezbûrenin [40b] yirmi dokuzuncu şekliyle.

C (ج): Ve bir müstakīm, iki müstakīmi iki noktada kat' edip, bir noktanın bir tarafda vakı'a olan hâricesi diğer noktanın yine ol tarafda vâkı'a olan dâhilesine ve kezâlik dâhilesi hâricesine berâber olsa, ol iki müstakīm, mütevâziyân olur, şekl-i mezbûrun 'aksiyle.

D (د): Bir sagīr müsellesin zâviyeleri, bir kebîr müsellesin zâviyelerine nazîr nazîre berâber olsalar, d1l'ları nazîr nazîre mütenâsib olurlar ve müsellesler birbirine şebîh olur. 
Ya'nî sagīrden bir zâviyenin veteri, kebîrden berâber olduğu zâviyenin veterine ne nisbet tutarsa gayrıların veterleri dahi berâberlerinin veterlerine öyle nisbet tutar, altıncı makālenin dördüncü şekliyle:

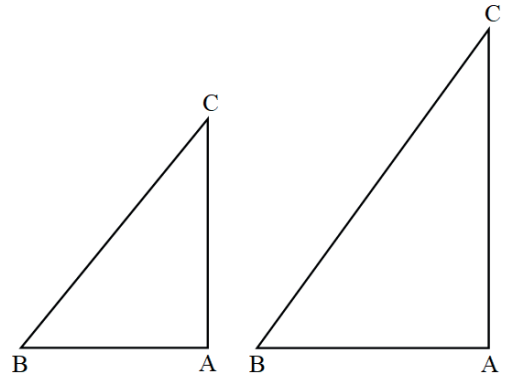

\section{Maksad:}

Keyfiyyet-i burhândadır. Menşe ve vasat ve mer'î mâbeynlerinde şu'â'-1 basarî ile tevehhüm olunan müselles-i kebîr, kâğıd üzerinde esnâ-yı 'amelde mersûm olan $A B C($ (اب (اب ) müselles-i sagīrine şebîh olup; menşe zâviyesi $A$ (।) zâviyesine, vasat zâviyesi $B(ب)$ zâviyesine, mer'î zâviyesi $C$ (ج) zâviyesine berâberdir. Zîrâ menşeden hedefeler ile mer'îye nazar olundukda tevehhüm olunan hatt-1 şu'â'î ol hâlde harf-i mistaraya muntabık resm olunan evvelki hatta mutâbıkdır ve $A C$ (اج) ol hattın cüz’üdür. Ve kezâlik yine menşeden 'alâmete nazar olundukda tevehhüm olunan hatt-1 şu'â'‘̂ ikinci hatta mutâbıkdır ve $A B(ا ب)$ ol hattın cüz'üdür. Pes menşe zâviyesi $A$ (') zâviyesine mutâbık ve berâberdir. Ba'dehu sepâ, vasata ve 'alâmet, menşeye vaz' olunup ve zikr olunan şartlara mürâ‘ât olundukda vasatda menşe mütevehhim olan hatt-1 şu'â‘î dahi ikinci hatta ya'nî $A B$ (اب) hattına muntabık olup, ol halde evvelki hatt ya'nî $A C$ (ج) hattı menşeden mer'îye mütevehhim olan hatt-1 şu'â'î ile mütevâziyân olur. $A\left({ }^{\prime}\right)$ zâviye-i hâricesi, menşe zâviye-i dâhilesine berâber olduğu için üçüncü mes'ele ile [41a] ba'dehu vasatdan mer'îye hedefeler ile nazar olundukda, mütevehhim olan hatt-1 şu'â‘î ve ana muntabık resm olunan üçüncü hatta, ki $B C$ (ب) hattı anın cüz'üdür, mütevâziyân olan $A C$ (جا) hattını $C$ (ج) noktasında ve menşe ve mer'î dıl'ını mer'î noktasında kat' edip, $C$ (ج) zâviyesi hârice ve mer'î zâviyesi dâhile ve ikisi dahi bir tarafda vâk1‘ olmakla birbirine berâber olurlar, ikinci mes’ele ile. Ve $B C$ (ب) hatt1, vasat ve mer'î dıl'ına muntabık olup $A B(ا ب)$ hattı dahi vasat ve menşe dıl'ına muntabık olmakla $B(ب)$ zâviyesi vasat zâviyesine muntabık ve berâber olur. Pes $A B C$ (الب ج) müsellesinden $A(l)$ zâviyesi müselles-i mütevehhimden menşe zâviyesine, $B$ (ب) zâviyesi vasat zâviyesine, $C$ (ج) zâviyesi mer'î zâviyesine berâber olmakla; $A B$ (اب) hattının menşe ve vasat dıl'ına nisbeti ve $A C$ (اج) hattının menşe ve mer'î dıl'ına nisbeti ve $B C$ (ب) hattının vasat ve mer'î dıl'ına nisbeti berâberlerdir. Çünki menşe ile vasatın mâbeyni olan dı1 ' zirâ' ile misâha olunup $A B$ 
(اب) hattı mikyâsdan zirâ' 'adedince dereceye müsâvî yapılmakla ol hattın dıl-1 mezkûra nisbeti derecenin zirâ‘a nisbeti gibi olup, sâ'ir hattların dahi nazîrleri olan dıl'lara nisbetleri dahi böyle oldu. İmdî $A C$ (اج) hattı derece-i mikyâs ile kaç derece ise nazîri olan menşe ile mer'î mâbeynindeki dıl‘ ol kadar zirâ‘ olur ve kezâlik $B C$ (ب) hattı kaç derece ise vasat ile mer'î mâbeyni ol kadar zirâ‘ olur.

Mühimme: Biraz sâha ber-vech-i muharrer misâha olundukda kâgıd üzerinde hudûs eden müsellesin adlâ‘ ve zevâyâsında ve sihhatde ol mahallde vâkı' kurâ vü kasabât ve buldân u tilâl ve eşcâr u ezhâr (اضحار) ve 'uyûn u enhâr ve sâ'ir mühim olunan nesneler mümkün olduğu rütbe nisbetince vaz' u işâret olunup, kâğıd tamâm oldukda ol mikdâr mahallin harîtası misâhasıyla müsvedde olmuş olur. Ve sâ‘atleri dahi takrîben ma'lûm olur. Zîrâ a'zam-1 dâ'ire-i arz ittifâkan üç yüz altmış derecedir ve müneccimûn ve coğrâfiyyûn bir dereceyi yirmi sâ' at i'tibâr ederler. Ve hükemâ batnı zahrına mülâsık altı dâne mu'tedil arpa mikdârına bir barmak deyip; mütekaddimîn otuz iki barmaga bir zirâ‘ ve üç bin zirâ‘a bir mîl [41b] ve üç mîle bir fersah, müteahhirîn yirmi dört barmaga bir zirâ‘ ve dört bin zirâ‘a bir mîl ve üç mîle bir fersah dediler. Mikdâr-1 fersah ikisine göre dahi şey-i vâhidden 'ibâretdir. Ancak bir derece mütekaddimîne göre yirmi iki fersah ve tis' fersahdır. Ya'nî altmış altı mîl ve sülüs mîldir. Müteahhirîne göre on dokuz fersahdan tis' fersah noksândır. Ya'nî elli altı mîl ve sülüsân mîldir. Pes mütekaddimîne göre bir derece kendi zirâ‘larıyla bir yük doksan dokuz bin zirâ‘ edip, bir sâ‘atin hissesi dokuz bin dokuz yüz elli zirâ‘ olur. Ve müteahhirînin zirâ‘larıyla iki yük altmış beş bin üç yüz otuz üç zirâ‘ ve sekiz barmak edip, bir sâ‘atin hissesi on üç bin iki yüz zirâ‘ ve on altı parmak olur. Ve müteahhirîne göre bir derece kendi zirâ‘larıyla iki yük yirmi altı bin altı yüz altmış altı zirâ‘ ve on altı barmak edip, bir sâ‘atin hissesi on bir bin üç yüz otuz üç zirâ' ve sekiz barmak olur. Mütekaddimînin zirâ'1yla bir yük seksen bin zirâ‘ edip, bir sâ'atin hissesi dokuz bin zirâ' olur. Lâkin hâlâ mi'mârların yirmi dört barmak diye isti'mâl eyledikleri zirâ', beyân eylediğimiz barmak ile otuz altı barmak olur. Zîrâ mi'mârî barmak ber-vech-i muharrer mülâsık olan dokuz dâne mu'tedil arpa mikdârı olup, iki mi'mârî barmak, üç barmakdan kinâye olur. Pes zirâ'-1 mi'mârî ile mütekaddimîne göre bir derece, bir yük yetmiş altı bin sekiz yüz seksen sekiz zirâ' ve yirmi bir buçuk barmak edip, bir sâ'atin hissesi sekiz bin sekiz yüz kırk dört zirâ' ve on buçuk barmak olur. Ve yine zirâ‘-1 mi'mârî ile müteahhirîne göre bir derece, bir yük elli bir bin yüz on bir zirâ' ve iki barmak olup, bir sâ'atin hissesi yedi bin beş yüz elli beş zirâ' ve on üç barmak olur. Ana göre hisâb olunup misâha olunan mahallin sâ‘ati dahi ma'lûm olur.

32 zirâ‘-1 mütekaddimîn 24 zirâ'-1 müteahhirîn 24 zirâ‘'-1 mi‘mârî

\begin{tabular}{|c|c|c|c|c|c|c|c|c|c|}
\hline 3 & \multicolumn{3}{|c|}{2} & \multicolumn{6}{|c|}{ İsba‘-1 hükemâ 1} \\
\hline & & & & 6 & 5 & 4 & 3 & 2 & 1 \\
\hline & 9 & 8 & 7 & 6 & 5 & 4 & 3 & 2 & 1 \\
\hline 2 & \multicolumn{9}{|c|}{ İsba'-1 mi'mârî 1} \\
\hline
\end{tabular}


Eczâ-y1 sâ‘atin sâniyeye kadar hisseleri bu cedvele vaz‘ olunmuşdur.

[42a]

\begin{tabular}{|c|c|c|c|c|c|c|c|c|c|c|c|c|}
\hline \multicolumn{13}{|c|}{ hükemâ kavlince eczâ-yı zamânın mikdârdan hisselerini beyân eder } \\
\hline \multicolumn{6}{|c|}{$\begin{array}{l}\text { 'alâ mezhebi'l-müteahhirîn fî̀ } \\
\text { mikdâri'd-derece }\end{array}$} & & \multicolumn{6}{|c|}{$\begin{array}{c}\text { 'alâ mezhebi'l-mütekaddimîn fî } \\
\text { mikdâri'd-derece }\end{array}$} \\
\hline \multicolumn{2}{|c|}{$\begin{array}{l}\text { zirâ'-1 } \\
\text { müteahhirîn }\end{array}$} & \multicolumn{2}{|c|}{$\begin{array}{c}\text { zirâ'-1 } \\
\text { mütekaddimîn }\end{array}$} & \multicolumn{2}{|c|}{$\begin{array}{c}\text { zirâ'-1 } \\
\text { mi'mârî }\end{array}$} & \multirow[b]{2}{*}{ ezmân } & \multicolumn{2}{|c|}{$\begin{array}{c}\text { zirâa'-1 } \\
\text { müteahhirîn }\end{array}$} & \multicolumn{2}{|c|}{$\begin{array}{c}\text { zirâ'-1 } \\
\text { mütekaddimîn }\end{array}$} & \multicolumn{2}{|c|}{$\begin{array}{c}\text { zirâ'-1 } \\
\text { mi'mârî }\end{array}$} \\
\hline zirâ‘ & isba & zirâa & isba' & zirâ‘ & isba' & & zirâ‘ $^{\circ}$ & isba & zirâ‘ & isba' & zirâ‘ $^{\circ}$ & isba' \\
\hline $\begin{array}{l}0 \\
\stackrel{0}{0} \\
\stackrel{0}{0} \\
\text { ה }\end{array}$ & $\stackrel{\circ}{-}$ & $\begin{array}{l}8 \\
\vdots \\
\dot{0} \\
-\end{array}$ & & $\begin{array}{l}\exists \\
\Xi \\
\vec{n}\end{array}$ & N & $\begin{array}{l}\text { derece } \\
\text { (20 sa'at) }\end{array}$ & 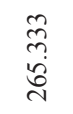 & $\infty$ & $\begin{array}{l}8 \\
8 \\
\stackrel{2}{2}\end{array}$ & & $\begin{array}{l}\infty \\
\infty \\
\infty \\
ٍ \\
ٍ\end{array}$ & $\stackrel{n}{\vec{N}}$ \\
\hline $\begin{array}{l}\stackrel{m}{m} \\
=\end{array}$ & $\infty$ & $\stackrel{8}{\circ}$ & & $\stackrel{n}{n}$ & 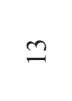 & sa'at & 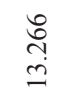 & $\stackrel{0}{-}$ & ஜू. & & $\begin{array}{l}\mathbb{Z} \\
\infty \\
\infty \\
\infty\end{array}$ & $\begin{array}{l}n \\
n \\
0 \\
0 \\
0\end{array}$ \\
\hline $\begin{array}{l}: \\
: \\
: \\
i\end{array}$ & $\underset{\sim}{0}$ & 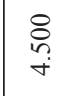 & & $\stackrel{尺}{\stackrel{i}{r}}$ & $\begin{array}{l}n \\
\infty\end{array}$ & nisf & రై & $\infty$ & $\stackrel{n}{\stackrel{n}{a}}$ & & $\underset{\text { Tे }}{\stackrel{+}{+}}$ & 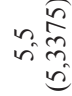 \\
\hline$\stackrel{\substack{\infty \\
i}}{i}$ & $\infty$ & $\stackrel{\substack{n \\
i}}{i}$ & & $\begin{array}{l}\infty \\
\infty \\
\infty \\
-\end{array}$ & $\frac{n}{\sqrt{2}} \frac{\widehat{a}}{\mathfrak{d}}$ & çâryek & $\stackrel{0}{m}$ & 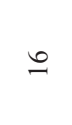 & $\stackrel{\substack{\infty \\
i}}{i}$ & $\underset{1}{0}$ & $\underset{\vec{\sim}}{\bar{i}}$ & 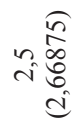 \\
\hline$\stackrel{\infty}{\infty}$ & 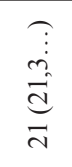 & $\stackrel{\circ}{n}$ & & $\cong$ & 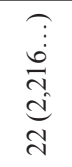 & dakīka & $\overrightarrow{\widetilde{N}}$ & $\begin{array}{l}\text { † } \\
\vdots \\
d \\
d \\
m\end{array}$ & $\ddot{6}$ & $\begin{array}{l}7 \\
\vdots \\
0 \\
0 \\
d \\
n \\
0 \\
i\end{array}$ & 守 & 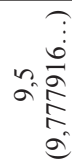 \\
\hline m & $\begin{array}{l}\overparen{\vdots} \\
\tilde{n} \\
\tilde{c} \\
\dot{\sigma}\end{array}$ & $N$ & $\stackrel{0}{\sim}$ & $N$ & 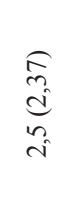 & sâniye & $m$ & 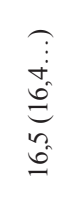 & $N$ & 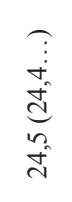 & $N$ & 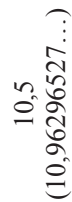 \\
\hline
\end{tabular}

Hâtime:

Bir cebel-i cesîm ya bir hısn-1 'azîmin mahall-i nazardan ru'yeti nisbetince şekl-i mücessemi ale'l-esheli'l-vech resm olunmak için ihtirâ‘ eyledikleri âletin evvela hey'eti: Bir barmak 'arzlı levhden masnû', dört zâviyesi kā'ime ve ancak her dıl'eyn-i mütekābileyni mütesâviyân bir mustatîlin bir dı1'-1 aksarı üzerinde kā’im, dı1'-1 atveline müsâvî bir 'amûd ve a'lâ-y1 'amûdda bir bekre ki, kutru bir isba' olup mihveri dıl'-1 atvele muvâzî dollâbî devr ede. Ve 'amûdun esfelinde her bir kā'imede dahi birer bekre ki, mihveri dil'-1 aksara muvâzî yine dollâbî devr ede. Ve 'amûdun mukābili olan dı1'-1 aksar üzerinde dahi bir bekre ki, mihveri 'amûda muvâzî olup rahavî devr ede. Ve bu dört bekrede cereyân eder bir hayt ki, üzerinde bir nokta [42b] farz olunsa, mustatîlin her dıl'1na muvâzî seyr edip 'amûda su'ûd ve nüzûl eder. Ve 'amûdda sâ‘id ve nâzil bir mâsûre ki, bir tarafına muttasıl hedefesi 'amûdun bir tarafında olan hayta geçirilmiş ve hedefenin lisânıyla hayt-1 kavâ'im üzere tekātu' eylemişler ve hayt-1 evvel, hedefeye merbût olup hayt cereyân etdikçe hedefe ma'an sâ'id ve nâzil olur. 
İsmine hedefe-i seyyâre denilse münâsib olur. Ve hedefe-i seyyâre tarafinda olan d1 $1^{\text {'}}-1$ atvele geçmiş bir bilezik ki, hayta merbût olup ol dahi cereyân etdikçe ma'an 'amûda kadar varır ve geri gelir. Lakin şol şartla ki, bilezik 'amûda kadar vardıkda seyyâre a'lâsına çıka, seyyâre esfeline indikde bilezik gerideki dıl'-1 aksara vara. Bileziğin taraf-1 hâricine muttasıl bir zeneb ki, ucu ile vaz' olunan mahalle bir nokta-i hayâliyye ihdâs eder. Mer'î denilse ba'îd olmaz. Ve 'amûd kāmetinde mustatîlden munfasıl bir levh-i tūlānī ki, bir müka'aba geçirilmiş bir tarafında sukbesi var, müka'ab içinde zīr ve bālā taharrük eder. Ve ol müka'abın mustatīl vaz' olunan mahallde 'amūd dıl'ina mukābil cânibde mevzi'i olmakla,burgu ile mevzi'ine ilsâk ve istihkâm olundukda mustatîl yemîne ve yesâra istikāmet-i adlâ‘1 üzere tesyîr olunsa ol müka'ab levhiyle mevzi inde sâbit olup asla hareket etmez ve sukbesi bâlâ tarafında olup seyyâreye mukābil bir hedefe olur. İsmine hedefe-i sâbite denilse vechi bulunur. Sâniyen 'ameli: hedefe-i sâbite mevzi'ine alsak ve mustatîl ber-vech-i muharrer önüne vaz' u ilhâk olunup, hedefe-i seyyâre 'amûdun esfeline tenzîl olunup, resmi murâd olunan nesnenin kā'idesi hedefeteynde ru'yet olunca sâbite dahi iktizâsına göre ya tenzîl ya tes‘îd olunup, ru'yet olundukda sâbiteye istihkâm verile. Ba'dehu sâbiteden nazar ve seyyâreden ma'an ol nesnenin bir köşesinin esfeli ru'yet olunup, mer'î ile bir nokta-i hayâliyye vaz' olunur. Ve mer’îyi 'amûda doğru sürmek ile seyyâreyi tesyîr ve ol köşenin esfelinden a'lâsına varınca kemer ve pencere gibi nesneler göründükce mer'î ile işâret oluna. Andan mustatîl diğer köşe cânibine tesyîr olunup, ol köşeye dahi ke'l-evvel nazar ve esfelinden a'lâsına dek [43a] mer'î ile işâret oluna. Ve cânibeyn mâbeyninde vâk1' burûc ve menâzır mu'lem olundukdan sonra tabla üzerinde hudûs eden nukātı, hutût-1 müstakīme ile îsâl ve pencereler dahi münâsebetiyle yapılıp ol nesnenin mücessemi hâsıl olur. Ve'l-hamdu li'l-lâh. 'Ale’t-tamâm.

Rakamehû câme‘ahû ahvecu'l-‘abîd ilâ keremi rabbihi'l-mecîd, Müftîzâde Muhammed Sa‘îd, gufira lehumâ fî leyleti'l-isneyn es-sâlis min şevvali'l-mükerrem li-seneti erba'a ve hamsîne ve mietin ve elf el-hicriyye 'alâ sâhibihâ elf tahiyye. [H. 1154]

\footnotetext{
Hakem Değerlendirmesi: Dış bağımsız.

Çıkar Çatışması: Yazar çıkar çatışması bildirmemiştir.

Finansal Destek: Yazar bu çalışma için finansal destek almadığını beyan etmiş̧ir.

Peer-review: Externally peer-reviewed.

Conflict of Interest: The author has no conflict of interest to declare.

Grant Support: The author declared that this study has received no financial support.
} 


\section{KAYNAKÇA / BIBLIOGRAPHY}

\section{Yazma Eserler / Manuscripts}

Ebû Sehl Numan Efendi. Tebyînü A'mâli'l-Misâha, İstanbul Teknik Üniversitesi (İTÜ), Nadir Eser Koleksiyonu TA590.E.292 1741, 109 yaprak.

Ebû Sehl Numan Efendi. Tebyînü A 'mâli'l-Misâha, Kandilli Rasathanesi, Türkçe Yazmalar 86, 99 yaprak.

Ebû Sehl Numan Efendi. Tebyînü A 'mâli'l-Misâha, Topkapı Sarayı Müzesi, Hazine 611/1, 1a-40b.

Mehmed Said Efendi. Risâletü'l-Misâha, İstanbul Üniversitesi Nadir Eserler Kütüphanesi, T6847, 9 yaprak. Mehmed Said Efendi. Risâletü'l-Misâha, Kütahya Vahidpaşa Yazma Eser Kütüphanesi, 729, 107b-114b.

Mehmed Said Efendi. Risâletü 'l-Misâha, Millet Yazma Eser Kütüphanesi, Ali Emiri Riyaziye 116, 8 yaprak. Mehmed Said Efendi. Risâletü'l-Misâha, Topkapı Sarayı Müzesi, Hazine 1753/4, 37b-43a.

Mehmed Said Efendi. Risâletü'l-Misâha, Topkapı Sarayı Müzesi, Hazine 609/1, 1b-8b.

Mehmed Said Efendi. Risâletü 'l-Misâha, Topkapı Sarayı Müzesi, Hazine 611/2, 41b-46a.

Mustafa b. İbrahim. Fenn-i Humbara ve Sanâyi '-i Âteşbâzî, İstanbul Atatürk Kitaplı̆̆ı, Muallim Cevdet Yazmalar1, K439, 79 yaprak.

Salih Zeki. Kāmûs-ı Riyâziyât c. IV, İstanbul Üniversitesi Nadir Eserler Kütüphanesi, T911.

\section{Basılı Kaynaklar / Printed Sources}

Adıvar, A. Adnan. Osmanlı Türklerinde İlim. 3. bs. İstanbul: Remzi Kitabevi, 1970.

Ahmed Vefik Paşa. Lehçe-i Osmanî. İstanbul: Mahmud Bey Matbaası, 1306.

Akbaş [Kocaman], Meltem. "Halifezade, Çınarî İsmail Efendi b. Mustafa," Lexikon der bedeutenden Naturwissenschaftler. Editörler Dieter Hoffmann, Huber Laitko, Staffan Müller-Wille, Bd. 2, München: Elsevier, Spektrum Akademischer Verlag, 2004: 150-151.

Ali Seydi. Resimli Kāmûs-ı Osmânî. C. 1. İstanbul: Cihân Matbaası, 1330.

Bahaeddin. Türkçe Lügat. İstanbul: İkbal Kitabhanesi, 1336.

Bir, Atilla ve Mustafa Kaçar. "Ottoman engineer Mehmed Said Efendi and his treatise on vertical sundial". Multicultural Science in the Ottoman Empire. Editörler Ekmeleddin Ihsanoglu, Kostas Chatzis ve Efthymios Nicolaïdis içinde 91-105. Turnhout: Brepols Publishers, 2003.

Bosnavi, Ömer. Bosna Tarihi. Ankara: Kültür Bakanlığı, 1979.

Bursalı Mehmet Tahir Efendi. Osmanlı Müellifleri. Hazırlayan İsmail Özen. C. 3. 2. bs. İstanbul: Meral Yayınlar1, 1975.

Çetin, Cemal. “Osmanlılarda Mesafe Ölçümü ve Tarihî Süreci”. Prof. Dr. Nejat Göyünç Armağanı. Editörler Hasan Bahar, Mustafa Toker, M. Ali Hacıgökmen ve Gül Küçükbezci içinde 443-466. Konya: Selçuk Üniversitesi Türkiyat Araştırmaları Enstitüsü, 2013.

Ebû Sehl Nu'mân Efendi. Tedbîrât-ı Pesendîde (Beğenilmiş Tedbirler). Hazırlayan Ali İbrahim Savaş. Ankara: Türk Tarih Kurumu, 1999. 
Emecen, Feridun. “Ahmed Paşa, Şehlâ”. Türkiye Diyanet Vakfi İslâm Ansiklopedisi. 2: 114. İstanbul: Türkiye Diyanet Vakfi, 2007.

İhsanoğlu, Ekmeleddin, ve Ramazan Şeşen. Osmanlı Astronomi Literatürü Tarihi. C. 1. İstanbul: İslâm Tarih, Sanat ve Kültür Araştırma Merkezi (IRCICA), 1997.

İhsanoğlu, Ekmeleddin ve Ramazan Şeşen. Osmanlı Astronomi Literatürü Tarihi. C. 2. İstanbul: İslâm Tarih, Sanat ve Kültür Araştırma Merkezi (IRCICA), 1997.

İhsanoğlu, Ekmeleddin, Ramazan Şeşen, ve Cevat İzgi. Osmanlı Matematik Literatürü Tarihi. C. 1. İstanbul: İslâm Tarih, Sanat ve Kültür Araştırma Merkezi (IRCICA), 1999.

İzgi, Cevat. "Nûman Efendi, Eğinli". Türkiye Diyanet Vakfi İslâm Ansiklopedisi. 33: 235-236. İstanbul: Türkiye Diyanet Vakfi, 2007.

Kaçar, Mustafa, ve Atilla Bir. “Osmanlı Mühendislerinden Mehmed Said Efendi’nin Dikey Duvar Saatleri Hakkındaki Risalesi”. Osmanlı Bilimi Araştırmaları 3, 1 (2001): 1-18.

Kaçar, Mustafa, ve Atilla Bir. "Ottoman Engineer Mehmed Said Efendi and his Works on a Geodesical Instrument (Müsellesiye)". Multicultural Science in the Ottoman Empire. Editörler Ekmeleddin Ihsanoglu, Kostas Chatzis ve Efthymios Nicolaïdis içinde 71-89. Turnhout: Brepols Publishers, 2003.

Kaçar, Mustafa. İlk Osmanlı Mühendis Hocası Mehmed Said Efendi ve İcad Ettiği Rub'-1 Müceyyeb-i Zülkavseyn (Müsellesiye) Adlı Mühendislik Aleti. Doçentlik tezi, İstanbul Üniversitesi, 2000.

Mehmed Salâhî. Kāmûs-ı Osmânî. C. 2. İstanbul: Mahmud Bey Matbaası, 1313.

Muallim Naci. Lugat-ı Naci. İstanbul: Asr Matbaası, 1317.

Muhammed Said. Manzum Küre Tarifnamesi. Çeviren Tahir Nejat Gencan. İstanbul: Kandilli Rasathanesi, 1973.

Öklid. Öklid'in Elemanları. Hazırlayan Ali Sinan Sertöz. Ankara: TÜBİTAK, 2019.

Polat, Atilla, ve Ali Demirci. "Kâtip Çelebi'nin Hendese Bilen Kadısına Müşahhas Bir Örnek: Eğinli Nu'mân Efendi”. Sahn-ı Semân'dan Dârüllfünûn'a Osmanlı'da İlim ve Fikir Dünyası Âlimler, Müesseseler ve Fikrî Eserler XVIII. Yüzyll. Editörler Ahmet Hamdi Furat, Nilüfer Kalkan Yorulmaz, ve Osman Sacid Arı içinde 2:157-77. İstanbul: Zeytinburnu Belediyesi Kültür Yayınları, 2018.

Polat, Atilla. "Treatises on Pergar-l Nisbe (the Sector) in Manuscript Collections in Turkey". Instruments Between East and West. Editörler Neil Brown, Silke Ackermann ve Feza Günergun içinde 39-54. Leiden \& Boston: Brill, 2019.

Raif Necdet [Kestelli] ve Hasan Bedreddin. Resimli Türkçe Kāmûs. 2. bs. İstanbul, 1927.

Redhouse, James W. A Turkish and English Lexicon. Constantinople: Boyajiyan, 1890.

Samy Bey Fraschery. Kāmûs-ı Fransevî Fransızcadan Türkçeye Lügat Kitabı. 4. bs. İstanbul: Mihran Matbaas1, 1322.

Şemseddin Sami. Kāmûs-ı Türkî. İstanbul: İkdam Matbaası, 1317. 